\title{
The rise and fall of the sand monopoly in colonial Hong Kong
}

\author{
Lawrence W.C. Lai, K.W. Chau and Frank T. Lorne \\ Ronald Coase Centre for Property Rights Centre \\ University of Hong Kong
}

\begin{abstract}
Keywords: Schumpeterian innovation, transaction costs, open access property, sand, state monopoly
\end{abstract}

\begin{abstract}
A state monopoly over a scarce natural resource under open access can arguably reduce the costs of supply by constraining rent dissipation. A monopoly over the collection and trading of sand was formed in Hong Kong by legislation in 1935 in the wake of disputes between sandmen and villagers and imminent shortages of sand. Arguably, a monopoly at this stage of Hong Kong's development was a better alternative to merely defining rights over sand extraction in terms of the transaction costs of enforcement. During the 1950s and 1960s, when Hong Kong's economy and construction industry began to boom, the monopoly's existence was further justified due to the politics of China being the sole source of Hong Kong's sand supply. However, this case study of the sand monopoly and its post-war operation as a bilateral monopoly shows that it did not protect coastal villagers, as violations of the sand law were not infrequent. The local sand supply was huge, and its abolition in 1981 was followed by a long period of falling, rather than rising, real wholesale prices of the resource. Nor was there any sign of scale economies, as claimed by the government. The policy implications of this are discussed.
\end{abstract}

\footnotetext{
"Where monopoly rests on man-made obstacles to enter into a market, there is every case for removing them." (Hayek 1960:pp.265-266)
} 


\section{Introduction}

The words of Hayek as quoted above pertain to the type of monopolies. In this paper, which investigates the genesis and destruction of a sand monopoly, reference will be made to some government-regulated monopolies that enjoy economies of scale, earn profits and crosssubsidize unprofitable services. There are also many examples of government departments providing monopoly services (like fire services) which do not charge a fee or (like water supplies) which charge on a cost-recovery basis, but they do not trade on other things in the economy. The state itself is, in fact, a monopoly of protection. The question is whether a state trading firm in a building material, sand, is sustainable. The discussion inevitably involves a cost dimension in relation to scale economies but the practical socio-ecological background is not so much cost of sand but the policy need to constrain rent dissipation in a de facto open access resource. Our chosen focus is whether a monopoly can solve a tragedy of the common problem; and our answer is no, even though theory would suggest that a granting of exclusive rights will result in optimal extraction. The question is Coasian: whether a state trading monopoly or state-regulated monopoly was a better institutional alternative, bearing in mind that there was econometric evidence that the latter did enjoy economies of scale in Hong Kong and survived as profit-making concerns.

Building construction and many industrial processes consume a lot of sand. In the making of concrete, sand is required to mix with cement and water. Sand is used to fill in the spaces left by stones and cement ${ }^{1}$. In Asia, river sand is preferred by contractors in making high-strength concreter and mortar. Sand naturally exposed on beaches or river banks can simply be removed using simple methods. Natural sand can also be found on seabed or river

\footnotetext{
${ }^{1}$ The usual ratios of the cement used in Hong Kong are: $M-15=1: 2: 4$ (cement: stones: sand); $m-20=1: 1.5: 3$ (cement: stones: sand) and $m-25=1: 1: 2$ (cement: stones: sand). The sand (ballast) provides strength, hardness, and durability. The cement binds the sand/gravel together.
} 
bed and dredging or siphoning is required to excavate it. Finally, sand can also be obtained by mechanically breaking up rocks. Beach sand can be captured or replenished by such engineering efforts as weir construction but the rate of exploitation must be carefully controlled.

In the policy arena environmental protection, the conservation of river and marine sand within a given territory has become a major sustainable concern. Ecological economists have paid much attention to measure its costs (Kim et al 2008). Governments often make laws and regulations to limit their exploitation because uncontrolled mining of coastal and riparian sand could not only cause ecological but also social problems, as violence would be used to appropriate state resources when competition becomes fierce.

To avoid or control these problems, the standard government practice is to limit sand excavation by law or administrative fiat to licensees. However, the most drastic practice is to establish a state monopoly on the quarrying and trading of sand. A Sand Monopoly existed in Hong Kong from 1935 to 1981.

Government legal monopoly of natural resource is nothing new to Hong Kong. New land for development is the classic example, as the state is at law the landlord of all land in Hong Kong with one single exception for a piece of land granted as freehold to the Church of England. The Fish Marketing Organization (FMO) established under the Fish Marketing Ordinance introduced after the Second World War was also the legal monopoly of non-living marine fish. Potable water supply has remained the monopoly of the Water Supplies Department. Lai and Yu (2002a) showed that the FMO ran into financial difficulties, as its trade-restrictive practices were bypassed by fishermen in the form of aquaculture and selling fish outside Hong Kong.

This article reconstructs the neglected history of a sand monopoly and seeks to evaluate the conjecture that it served the purpose of keeping sand prices low as a social policy. Special 
attention has been paid to the likelihood of scale economies, which lends support to the presence of a monopoly.

\section{Theoretical context: property rights, monopolies and transaction costs}

The discussion on this ecological resource is informed by theories on property rights, monopolies and Coasian transaction cost.

\section{Property rights}

In mainstream economics, it is "received theory" that the establishment of exclusive property rights over natural resources could not only limit rent dissipation by curtailing access but also encourage investment and innovations by creating titles to the resources. Evidence of this has been found in marine creatures, which actually inspired the genesis of the term "the tragedy of the commons". From their studies on the economics of cultured versus captured marine fish, it has been found (Lai 1993; Lai and Yu 1995; Lai and Yu 2002b; Chau and Ho 2002) both the prices and quantity supply of domesticated species are much more stable than wild ones, as planned production and inventory is only feasible for the former. By similar reasoning, such natural resources as minerals and wood subject to more access restrictions would exhibit a similar pattern of resource allocation.

In resource and neo-institutional economics, fisheries (Gordon 1954, Cheung 1970, Lai 1993, Lai and Yu 1995) and trees have been treated by models of rent dissipation on a par with gold (Umbeck 1981), coal (Anderson and Hill 1981) and crude oil (Libecap and Wiggins 1985). Sand should not be an exception as it is also in short supply. It is true that renewable resources theoretically can be treated differently than minerals, sand in this case. However, the nature of sand and sand mining is also interesting in one aspect. Unlike lining organisms, say, fish or human beings (who can be subject to slavery), but like gold (Umbeck 1981), sand can neither "adapt" to human intrusion nor negotiate with its own conservation. Its protection, as in the case of trees, lies entirely on the will and wisdom of property management, if any, as regards access control and investment. But unlike goldmines where exclusive rights are usually granted 
if not created (Umbeck 1981), marine sand is scattered all over coastline where in other regions of the world, it probably is not considered to be a scarcity problem. This makes the Hong Kong study unique. Because of the hectic construction activities on this insular city region, sand became a scarce commodity. Depletion of that could be similar to the depletion of any minerals which are usually treated to be much more valuable to be protected by the country where the minerals are found. The laws in those countries will be explicitly structured to prevent over exploitation. On the distinction between renewable versus mineral resources, the difference could be a matter of formulation. Instead of aiming at maximum yield, exploitation should aim for sustainable yield. Again, the question would be, what type of institution that will be best to provide for a sustainable yield.

On the distinction between renewable versus mineral resources, the difference could be a matter of formulation. Instead of aiming at maximum yield, exploitation should aim for sustainable yield. Again, the question would be, what type of institution that will be best to provide for a sustainable yield.

The standard approach to economic research following the above line of thinking focuses on the prices of the resources. This paper adopts that approach and examines if the sand monopoly had an impact on price. This concern with prices should be viewed in light of the considerations that prices are amenable to empirical analysis, as prices are observable.

\section{Monopolies}

Pigovian economists have long taken up arms against monopolies as a type of market failure on the basis of "efficiency". The three types of market failure were external effects; public goods, and monopoly. Each type of market failure involves an efficiency problem, such as an inequality between marginal valuation (MV) and marginal cost (MC). Any government policy seeking to

distinguish between the two may or may not achieve the equity rule, which requires distinguishing between average revenue (AR) and average cost (AC). The constant marginal cost 
monopoly can be driven to produce at an efficient ( $M V=M C$ ) equilibrium, which is also the break-even $(\mathrm{AR}=\mathrm{AC})$ point. $^{2}$

There are several libertarian approaches for defending a monopoly. First, to punish a monopoly is the same as punishing a firm that is successful. This has a "disincentive effect". Second, most arguments against monopolies are based on a static view of the economy. In reality, facing potential competition, monopolies will push costs down and lower prices to discourage rivals from entering the market. The shifting down of the supply functions can be explained in terms of the differences between Coasian and Schumpeterian economics (Lai and Lorne 2014). The latter focuses on institutional reforms that facilitate a more efficient identification of parties to contract, negotiation, bargaining, etc., so that the maximum welfare under a given set of demands and cost conditions is attained. The former considers efficiency in transactions under given cost conditions less important than innovation, which is the real driving force of the economy. Innovate or die.

In this paper, there is no a priori vale assumption that that economic efficiency should not be the sole or even decisive consideration. The 1933 state franchising of trams, public buses, and ferries, which, in a way, departed from the establishment of London Transport in Britain, was instituted at about the same time the sand monopoly was created. But only the

\footnotetext{
${ }^{2}$ The rising marginal cost monopoly can also be driven to produce at the efficient ( $\mathrm{MV}=\mathrm{MC}$ ) equilibrium, which is above the break-even point. Political pressures tend to move the monopoly to the break-even point by sacrificing some efficiency. The decreasing cost monopoly (often called a "natural monopoly") cannot break even and, in fact, would result in a loss if it is forced to produce at the efficient point ( $\mathrm{MV}=\mathrm{MC}$ ). This is the key efficiency reason for nationalization (the state taking over ownership), as in the case of water supplies and telecommunications. Public policies forcing or bargaining to induce a constant MC monopoly to produce at an efficient level of output are feasible, as that is identical to the break-even solution. No public subsidy is necessary for attaining an efficient output. Public policies forcing or bargaining to induce a rising $\mathrm{MC}$ monopoly to produce at an efficient level of output are also feasible, as the firms can still retain some abnormal profit. However, pro-labour groups would tend to pressure the state to require firms to produce at (greater) break-even and less-than-socially-efficient levels. Public policies forcing or bargaining to induce a falling MC (or "natural") monopoly to produce at an efficient level of output are not feasible for private firms unless there they are given state subsidies. Either the profit-maximizing or break-even level of production is feasible for the firm, but neither is sufficiently efficient due to underproduction. This kind of monopoly is particularly susceptible to nationalization or direct state operation.
} 
last was terminated by a decision of the same administration that formed it. This case study in this context was a diagnosis of the problems that led to its destruction.

There are three prevailing views in the literature on the "state monopoly," "state trading monopoly," or "government monopoly". One view is that it is always or tends to be inefficient (see, for instance, Clarke and Wallsten (2002), Olukoju (2004), Slater (2006)), and hence, deregulation would lower prices. The other view is that there is a need to study each case on its own merit based on the facts (see, for instance, Burnell and Sheppard (1992); Roberts (2001)). This view, often advanced by defenders of state monopolies against privatization or international/regional free trade protocols, is theoretically supportable by the possibility that a natural monopoly can innovate and lower its long run average cost and enjoy scale economies (see, for instance, Howorka (1981)). ${ }^{3}$ The third view is about the origin of state monopolies as protectionist measures using the concept of rent-seeking (Watts 1984, Hutchcroft 1991, Lu 1999). It is possible that rent-seeking can completely dissipate the monopoly rent. However, the focus of the paper is on whether the tragedy of common problem can be solved by the granting of ( $a$ particular type of) monopoly. This paper did not dispute the existence of social costs to the farmers and other users of sand (e.g. beachgoers) or whether regulation was deemed necessary. It does take issue with the specific mode of monopoly chosen.

Hong Kong's franchised bus and ferry companies, which are privately, rather than government, run, are cases in point (Lai, Chau, and Cheung 2012). The starting point of this paper on whether a given state monopoly raised or lowered prices is an empirical question. Informed by Coasian economics, it holds that any public interest justification for state

\footnotetext{
${ }^{3}$ In the age of liberalization, the general tendency is to privatise state monopolies so that they act according to market principles and, hence, become more efficient (see, for instance, Morgan (1992), Fielding and Klein (1993)). One of the supporting tenets is that state control of its own monopolies is hopelessly ineffective (see Chaudry (2000)). Prager's (1994) idea that a government monopoly can be more efficient than a regulated private monopoly is a rare one. In any event, state monopolies are under close scrutiny, if not outrightly condemned, almost all the time (see Waller (1981), Papathanassopoulos (2005)). During the 1930s, this consideration led to the government takeover of private monopolies (see, for instance, Hooper, Hutcheson, and Nyathi (1996)).
} 
intervention, granted valid, did not entail the creation of a sand monopoly in the form it assumed as the only policy option.

\section{Transaction costs}

Generally, transaction costs in the tradition of Coase (1960) are costs that cannot be modelled by a neo-classical production function, or costs of institutions (Cheung 1998). Costs of competition for resources under open access are transaction costs and institutions (i.e., exclusive property rights regimes or arrangements of various degrees of whether communal or private property rights) would emerge to constrain such costs. These arrangements may evolve slowly over time by trial and error and mutual agreement as in the case of Crown franchising of private lighthouses (Lai, Davies and Lorne 2008) but modern governments have a propensity to create new institutions by edict. These new institutions are often monopolies. Sand in a jurisdiction by definition is not de jure common property but the private property of the state. However, the costs of enforcing against poaching are so high that it is normally de facto open access. In so far as competition for the use of sand is low, the state would not bother to alter the status quo. However, when violence in competition for a resource with the jurisdiction of a state is rampant, state intervention by fostering some institutional arrangements to constrain the transaction costs are expected. However, institutions do not stop short of improving efficiency by reducing transaction costs, the gist of Coasian economics. Given suitable conditions, they can even promote innovations (Lai and Lorne 2014). But the question is what should be the mode of such arrangement?

\section{Sand Mining in Hong Kong before the Formation of the Sand Monopoly}

While the Hong Kong Government now actively substitutes for sand, ${ }^{4}$ there has been neither scholarly work nor released official publications on the production of this material. The extant literature on sand mining in Hong Kong is scanty and what available suggests that it was replete

\footnotetext{
${ }^{4}$ A task force was set up within the Construction Industry Council to provide advice to the "River Sand Substitutes Research Project".
} 
with problems ab initio, notably disturbance to local graves as well as coastal cultivation. Such literature was generated by officials, expatriate cadet officers from Britain, who subscribed to the idea that sand was running out and its digging had to be centrally controlled by the government.

Sand has always been government property. In a file minutes regarding the restrictions on sand mining, Philip Jacks, Land Officer, pointed out that "Sand is reserved to the Crown in all Crown Leases in this Colony, ${ }^{5}$ and the unauthorized taking of sand was prohibited. The mining of sand required a special permit, but the earliest day that the system was introduced was, unfortunately, untraceable. However, it is certain that by 1903, a permit system for sand disposal on Crown Land was in place. ${ }^{6}$

In the leased New Territories, sand mining required a permit subject to the regulation stated in Government Notification No.328 (G.N. 328) of 1905. ${ }^{7}$ A minor amendment to G.N. 328 was introduced in 1907 by Government Notification No.218 (G.N.218) of the year. ${ }^{8}$

During the early $20^{\text {th }}$ Century, several instances of sand mining in the New Territories raised the government's awareness of the problems of sand removal, authorised or otherwise, and led to its intervention. The first occasion in 1906 arose from a licence granted a year earlier to mine sand in Kau Wa Ken[g] Village. Villagers there complained of trespassing, as "some boatmen in lighters have dug sand from within the boundaries of petitioners' land and they also destroyed the boundary stones fixed by petitioners. The said piece of land protects petitioners' field from inundation in case of bad weather." 9 Facing the problem of excessive mining, the government considered cancelling the permit that was granted in 1905 . The consequences of

\footnotetext{
${ }^{5}$ Philip Jacks to E.W. Hamilton (28 JUNE 1920), Enclosure 2, C.S.O. No.1299/1920 (PRO Ref: HKRS58-1-95-10).

${ }^{6}$ Hong Kong Government (1903: 252).

${ }^{7}$ Government Notification No.328, The Hong Kong Government Gazette, 26 May 1905.

${ }^{8}$ Government Notification No.218, The Hong Kong Government Gazette, 5 April 1907.

${ }^{9}$ Petition by Tsang Tai Shang and others of Kau Wa King Village, 23 May 1906, C.S.O. Files No.4402/1906 (PRO Ref: HKRS58-1-36-13).
} 
this incident are still unknown. ${ }^{10}$ The next occasion, however, triggered a chain of government responses.

In August 1920, excessive sand mining of coastal sand bars in Mui Wo was reported. Eric William Hamilton, the Assistant District Officer of the Southern District, drew up a Memorandum on the Supply of Sand for Building Purpose, which described the problems of coastal erosion, as landowners allowed contractors that held permits from the Building Authority to take sand from their lands and urged the government to formulate a "definite policy of dealing with the matter."11

Hamilton's memorandum was circulated to the Land Office and Public Works Department, whose officials, along with those in the District Office, South, agreed that "sand deposit should be controlled," that "[t]he working of the deposit should be carefully regulated and any junks found taking it away without a permit dealt with severely," but that a "permit should not [be] [sic] restricted to Government Contractors as it will only be an inducement for them to sell sand to other Contractors or use it on private works that they may be engaged [on] [sic]". ${ }^{12}$ After resuming the land at Mui Wo, Hamilton carried on proposing tighter restrictions on sand taking. ${ }^{13}$

Hamilton's proposal was approved by the Governor, and the drafting of a new government notification was underway. The result of this discussion was not yet known though, as the government's tendency to tighten up the restrictions on sand-taking was, after all, apparent.

\footnotetext{
${ }^{10}$ Land Removal of Sand from Foreshore at Kau Wa King Village, 23 May 1906 to 5 July 1906, C.S.O. File No.4402/1906 (PRO Ref: HKRS58-1-36-13).

${ }^{11}$ Enclosure 2.1: Memorandum on the Supply of Sand for Building Purposes (25 June 1920), C.S.O. File No.1299/1920 (PRO Ref.: HKRS58-1-95-10).

${ }^{12}$ Enclosure 2, Minutes between Assistant District Officer (South), Land Officer and Director of Public Works, C.S.O. File No.1299/1920 (PRO Ref.: HKRS58-1-95-10).

${ }^{13}$ Hamilton to Colonial Secretary, 2 November 1920, C.S.O. Files No.1299/1920 (PRO Ref.: HKRS58-1-95-10).
} 
In 1931, Edwin Richard Hallifax, the Colonial Secretary, issued Government Notification No.193 (G.N.193) of 1931, regarding sand taking along the Crown foreshores. However, the notice was "for information" only, reflecting a non-interventionist stance. ${ }^{14}$

Another glimpse of the problem up to the 1930s can be gained from the memoir of Walter Schofield (1987), a District Officer. The rush for sand led to erosion and gun violence.

One of the subjects which used to excite much feeling in the Chinese countryside was the disturbance of graves. In 1930 this occurred at Tai Wan in Lamma, on the big sand bank later excavated by Father Finn, once a leading local centre of Bronze Agriculture. The sand diggers had cut away so much sand that coffins buried 2 feet deep in the bank were sticking out, and their contents could be seen.

One crime that often came before my court in the office was stealing sand for building. Sand collecting was regulated by a system of permits, allowing junk masters to collect sand at selected beaches, each junk having its own collecting beach. Sand shortage was serious from 1924 to 1926, when concrete was coming into fashion for building, and between the demands of builders, and the interests of New Territory cultivators of land behind the sand banks, there was acute conflict, which sometimes grew into a shooting match. One such conflict took place at Sha Lo Wan in Northwest Lantau; this village was very jealous of the fine sandbank protecting its fields, and had licensed gun owners; so the crews, who had no permit for that beach, were driven off without their sand.

According to a 1933 report on the New Territories,

The demand for sand continues to be keen. 294 permits were issued as against 249 for 1932 and the resultant fees show an advance of $\$ 1,887.00$. The denudation of the

\footnotetext{
${ }^{14}$ Government Notification No.193 of 1931, Hong Kong Government Gazette, 27 March 1931. See also C.S.O. Files No.1342/1925 (PRO Ref.: HKRS58-1-135-75).
} 
beaches in the District by sand thieves continues to cause concern. In spite of much hard work and extra precautions on the part of Police launches, and heavy sentences on offenders when convicted, the nuisance is still only partially checked. Maximum penalties are now being exacted in an effort to stamp out this offence. ${ }^{15}$

During the 1934 Budget debate, the Colonial Secretary told the Legislative Council that due to "the rapid exhaustion of the sand supplies of the Colony," a scheme would be undertaken to be laid before the Council at an early date. It was anticipated that the scheme would "not only pay for itself but will bring in a small addition to the revenue" when it was in full operation. ${ }^{16}$

The public policy concern over this state of affairs, notably the use of violence involving firearms to demarcate the rights over the supposedly scanty resource, was surely one of the key reasons why a sand law and sand monopoly came into existence in 1935 . The classic case for a state monopoly to constrain transaction costs/rent dissipation was ripe. Note, however, that the District Officers were not geographers and neither they nor the lawmakers had the benefit of having surveyed sand deposits in the colony.

\section{Creation and Evolution of the Sand Monopoly}

On 8 November, 1934, the Attorney General proposed to the Legislative Council the Bill of a Sand Ordinance. In his speech, he told the Council that:

The purpose of this [Sand] Ordinance is not to secure revenue, though it is expected that the monopoly will bring in a small return, but to safeguard the Colony's sand supplies which have of late become much depleted. The establishment of a monopoly

\footnotetext{
${ }^{15}$ Report on the New Territories for the Year 1933, Appendix J, Annual Report on the Social and Economic Progress of the People of the Colony of Hong Kong during the Year 1933, p.20.

${ }^{16}$ Hong Kong Hansard (1934a: p.112).
} 
and the employment of specially marked sand junks will facilitate the detection of sand thieves. ${ }^{17}$

The Bill was passed on 22 November, 1934. The legislation had to be made as a reaction to a quite serious public issue to the extent that the law reversed the common presumption of not guilty in favour of the accused. Therefore, when this Ordinance was presented to the Colonial Office, it was met with disallowance, as the Office objected to a clause that placed the burden of proof on the defence (Miners 1988: p.240). The Bill of the amended Ordinance was put before the Legislative Council again and was passed on 5 October $1935 .^{18}$

The Sand Amendment Ordinance of 1938 (Ordinance 12) vested the authority to issue sand removal permits upon the Director of Public Works for the first time (Section 2(1) of Ordinance No.50 of 1935) and introduced a maximum fine of $\$ 500$ for any violation of it (Section 4 of Ordinance No.50, 1935). It also established a government Sand Monopoly (Section VI, Financial Report for the Year 1939, 25 April 1940) and transferred the monopoly to a newly-established Department Controller of Government Store, ${ }^{19}$ with power of arrest Section 3 of Ordinance No.12, 1938).

The transfer of authority from the Director of Public Works to the Controller of Stores was probably to facilitate a vertical integration of power as at creation, the Sand Monopoly was a major branch of the Stores Department. It controlled both the production and trade of sand. It restricted sand collection to designated places through licensing, established sand depots and reserve dumps, and imposed price controls on all sand collected.

We do not know of anything about the institutional arrangements for sand mining during the years of occupation of Hong Kong by the Japanese authority from 25 December 1941

\footnotetext{
17 Hong Kong Hansard (1934b: p.210).

${ }_{18}$ Hong Kong Hansard (1935: p.247).

${ }^{19}$ Government Store, Colonial Office File No.53896/1938. Hong Kong (British National Archive Reference: CO 129/572/13).
} 
to 15 August $1945 .^{20}$ However, the Stores Department was quickly rebuilt with the Sand Monopoly after the war. As late as the early 1960s, the Sand Monopoly was staffed by just two civil servants: an expatriate officer and a local Chinese "General Clerical Service (GCS)II" (Clerk II).

In 1965, the Stores Department was renamed Government Supplies Department (GSD).

On 1 January 1970, the power of the sand monopoly, minus the authority to license sand extraction in the New Territories, eventually reverted from the GSD to the PWD by an amendment to the Sand Ordinance in 1970 (No.66 of 1970; passed 17 June 1970 and assent granted 19 June 1970). While the PWD retained a monopoly to set prices on sand, the amendment expressly exempted "sand produced by any quarrying operation or by the washing of other material" from regulation. This was supposed be a move to promote innovations in sand manufacturing.

The sand monopoly, as the sole supplier of sand in Hong Kong, was finally disbanded in June 1981. The 1982 Annual Report read, "With the Government Sand Monopoly being discontinued in June, marine and river sand brought in from China is now being sold directly by the importers while manufactured sand is sold by the quarry contractors" ((Hong Kong Government 1982: p.160). Since June 1981, contractors have been able to buy sand directly from any source apart from the PWD. ${ }^{21}$

\footnotetext{
${ }^{20}$ During Japanese occupation of Hong Kong from 25 December 1941 to 15 August 1945, there was virtually no new private development as the Japanese imposed a policy of reducing the local Chinese population by forced repatriation to their villages in Mainland China. An exception was the creation of the "kei wei" (inter-tidal fish/shrimp ponds) in Mai Po Marshes, which has become an international migratory bird conservation and watching site. Nearly all public works were connected with military or occupation purposes, notably the expansion of the Kai Tak Airport; construction of a road to the top of Tai Mo Shan to serve a military radar station; extension of the Clear Water Bay Road in the direction of Sai Kung to fight communist guerrillas, the building of concrete pillboxes at Luk Keng to counter an Allied landing; the erection of a war memorial for Japanese war casualties on the summit of a knoll in Mount Cameron; and addition of a Japanese style tower to the Governor House. All such engineering works involved the extensive use of concrete and fill materials but unfortunately we know nothing about the means and quantity of sand exploitation.

${ }^{21}$ The PWD was "defederalised" in 1982 in to a large number of lands and works department. The original function of the monopoly in controlling local sand mining was vested in 1982 in the Engineering Development
} 


\section{Criticisms and Government Justification of the Sand Monopoly}

Once established, departments competed to control the Sand Monopoly. Forces within the government indeed built up soon after the post-war return of the British Administration, which gradually led to the eventual transfer of the sand monopoly from the hands of the Controller of Stores to those of the engineers working in the Public Works Department, which controlled and ran government quarries.

Our archive research revealed that as early as 1946, tension had built up between the Controller of Stores, acting in the interest of the building industry, and the Public Works Department, which sought to protect bathing beaches listed under the First Schedule to the Pleasure Grounds and Bathing Places Regulation Ordinance No.29 of 1936 over the removal of sand from beaches. ${ }^{22}$ Besides, from the beginning, the sand mining activities of the Controller of Stores also faced challenges from the Agriculture and Fisheries Department and the New Territories Administration, acting on behalf of the farming, fishing, and oyster cultivation communities. The Urban Services Department (USD), which had jurisdiction over urban Hong Kong outside the New Territories, had an interest in preserving the sand in the beaches for recreation purposes. It sought technical help from the UK in 1963 by writing to the Hydraulic Research Station at Wallingford, Berkside on the possible measures to conserve marine sand on the beaches it controlled. ${ }^{23}$

Back in 1950, in response to looming environmental and social concerns, the legislator reassigned the authority to issue permits to remove sand in the leased New Territories, Hong

\footnotetext{
Department (EDD), which was re-christened the Civil Engineering Services Department (CESD) in 1986 and became the Civil Engineering Department (CED) in 1991. In 1986, the engineers regained by law full control over sand extraction licensing throughout all of Hong Kong, while the District Commissioner function had already ceased to exist due to major district administrative reforms during the early 1980s.

${ }^{22}$ See Memo PWD 820/46 dated 16 September 1946 from the Director of Public Works to the Colonial Secretary (PRO Ref. HKRS 156-1-368).

${ }^{23}$ See Letter Ref.102/5/26, dated 28 May 1963 from the Director of Hydraulic Research to the Director of Urban Services (PRO Ref.HKRS 41-1-10591).
} 
Kong's rural hinterland at the time, from the Controller of Stores to the District Commissioner. ${ }^{24}$ This was effected by the Law Revision (Miscellaneous Amendments)(No.3) Ordinance (No.37 of 1950), which added a new Section 3B. Losing the authority to control sand production in the New Territories, which meant a substantial part of Hong Kong, the Stores Department sought to fill up its depots and continue its regulated trade of sand by seeking contractors that could extract marine sand offshore. This move by a state monopoly holder of the sand trade entailed radically new methods of extraction, which fostered to create a private monopoly of sand production to drive out labour-intensive competitors by capital-intensive methods.

From official documents, it appears that the private sand-seeking industry was indeed also monopolized after the war. It was stated that all sand contractors for the sand monopoly almost always sub-contracted their work to the "Sand Junks Association (SJA)" [Hong Kong and Kowloon Sand Junks Merchant Association], which had, thus, monopolized the trade of manual sand extraction from the beaches. This bilateral monopoly (the government sand monopoly had a monopsony and the private SJA a monopoly over sand) can be considered a means to constrain rent dissipation due to over-competition. Theoretically, this was more efficient.

The monopoly faced complaints soon after the end of the war. The first wave of criticism of the Controller of Stores' sand monopoly did not come from the public, but from within the government. On 2 August 1946, approximately a year after the end of the Pacific War, S.E. Faber, the Director of Building Rehabilitation, wrote a complaint to the Financial Secretary about the cost of sand under the monopoly:

I understand that the Government Stores are at present re-organizing the sand supply, and will soon be in a position to sell sand for building purposes. I understand also that a considerable [amount of] revenue is expected from this source.

\footnotetext{
${ }^{24}$ Hong Kong Hansard (1950: p.336).
} 
It is however clear that sand costs, which are almost entirely transportation by junk, will be very high, compared with prewar lev[e]ls, since the critical shortage of junks has raised their charges to from $\$ 80-\$ 120$ per day.

In view of the deterrent effect on rebuilding of high building costs, of which sand is a factor, although not the major one, I would recommend that for the next 12 months, or so, the cost of sand should be kept almost at cost; as transportation costs decreases with greater competition amongst junk owners, the cost price will drop and a greater profit become available as revenue. ${ }^{25}$

Upon request by the Financial Secretary about this complaint, the Controller of Stores ${ }^{26}$ agreed that the monopoly's profits could be reduced:

Prewar selling price was approximately $70 \%$ above cost and on this basis we made a profit of $\$ 250,000$ a year.

Cost prices, due mainly to increased transport charges, will be considerably higher now, and the revenue (if the $70 \%$ profit basis is adhered to) will be proportionately large.

This, plus a larger building programme, should bring a substantial return, estimated at $\$ 1,250,000$ a year.

It might meet both sides if percentage over cost was reduced by half. ${ }^{27}$

It was eventually agreed that the profits would be reduced to $35 \%{ }^{28}$

\footnotetext{
${ }^{25}$ Enclosure 1: S.E. Faber (Director of Building Rehabitation) to Financial Secretary, 2 AUG 1946, General Correspondences Files, Building and Lands No.7/736/1946 (PRO Ref.: HKRS156-1-368).

${ }^{26}$ Financial Secretary to Controller of Stores, 8 AUG 1946, General Correspondences Files, Building and Lands No.7/736/1946 (PRO Ref.: HKRS156-1-368).

${ }^{27}$ Controller of Stores to Financial Secretary, 23 AUG 1946, General Correspondences Files, Building and Lands No.7/736/1946 (PRO Ref.: HKRS156-1-368).
} 
Then another complaint was raised by the Director of Public Works, who accused the Controller of Stores of granting permission to contractors to remove sand from bathing beaches such as Deep Water Bay, Repulse Bay, Stanley Bay, and Island Bay. Under the authority granted by the Pleasure Grounds and Bathing Places Regulation Ordinance (No.29 of 1936), the Director asked the Controller of Stores to obtain his consent before granting sand removal permits for 21 beaches in the Colony. ${ }^{29}$ The Controller of Stores replied:

Though very lak [sic] in the any I can give Hon. D.P.W. the assurance that no beaches are open for the removal of sand without his prior approval or that of D.O. for N.T. I instituted this procedure - as in former practice on my return to duty .... ${ }^{30}$

Outside government, local building contractors raised concerns over the high price of government-supplied sand. In mid-1947, they formed a Building Cost Committee ${ }^{31}$ with the objectives of investigating the extent to which the cost of construction had risen since 1938 and to suggest a series of practical methods to reduce the cost of construction. The supply, price, quality, and transportation of sand concerned the committee.

(b) The marketing of sand is a government monopoly, introduced to conserve beaches. The supply has not kept pace with the demand due in part at least to the shortage of junks required to collect it. Jobs have been held up through the lack of sand, and lorries have stood many hours at sand depots waiting for supplies. This has caused increases in building costs.

\footnotetext{
28 [IIlegible] to Financial Secretary, 27 AUG 1946, General Correspondences Files, Building and Lands No.7/736/1946 (PRO Ref.: HKRS156-1-368); [lllegible] to Director of Public Works, 27 AUG 1946, General Correspondences Files, Building and Lands No.7/736/1946 (PRO Ref.: HKRS156-1-368); Director of Public Works, 9 SEP 1946, General Correspondences Files, Building and Lands No.7/736/1946 (PRO Ref.: HKRS156-1-368).

${ }^{29}$ Enclosure 2: Director of Public Works to Colonial Secretary, 18 September 1946 (PWD No.820/1946), General Correspondences Files, Building and Lands No.7/736/1946 (PRO Ref.: HKRS156-1-368).

${ }^{30}$ Controller of Stores to Financial Secretary, 27 MAR 1947, General Correspondences Files, Building and Lands No.7/736/1946 (PRO Ref.: HKRS156-1-368).

${ }^{31}$ Enclosure 1: G.L. Wilson to the Governor, 19 AUG 1947, General Correspondences Files, Building and Lands No.BL1/2/736/46 (PRO Ref.: HKRS156-1-360).
} 
(d) Sand, as delivered from Government bins, is not washed or graded, and is of inferior quality. To use it, it has to be screened or washed by contractor, who naturally passes the cost of this on to the building. Although grading was not carried out by government before the war, sufficient stocks from various beaches were held segregated, permitting the most suitable sand for any purpose to be selected. There are at present not sufficient stocks to allow of this practice, and contractors are forced to accept "sand" as such, whatever quality. ${ }^{32}$

The committee recommended that "The shortage of sand may be overcome by [the] Government opening selected beaches where sand can be dug and graded by private enterprises under permit and adequately controlled." 33

The Controller of Stores opposed the Committee's recommendation on the grounds that allowing "sand to be dug by private enterprise would revert back to the old days when private individuals obtained a permit for a nominal sum to collect as much sand as [t]he[y] wanted were spoiled and compensation had frequently to be paid for damage caused to paddy and vegetable crops." 34 He added that the supply of sand had not, at the time, been insufficient, and that the congestion caused by vehicles carrying sand resulted from the uneven distribution of traffic every week. The Controller evaded the question of quality control and simply stated that sand was classified as "fine, medium and coarse". 35

Legislator Man-Kam Lo was a persistent critic. When he asked about the implementation of the Report of the Building Cost Committee, the Colonial Secretary replied

\footnotetext{
32 Enclosure 31: Report of Building Cost Committee 1947-48, General Correspondences Files, Building and Lands No.BL1/2/736/46 (PRO Ref.: HKRS156-1-360).

33 lbid.

${ }^{34}$ Enclosure 10: Watson to Barty, 1 SEP 1948, General Correspondence Files, Building and Lands No.2/736/1949 (PRO Ref.: HKRS156-1-1883).

${ }^{35} \mathrm{Ibid}$.
} 
that it "found itself unable to accept the recommendation that sand should be dug and graded by private enterprise" 36 on consistent grounds with that of the Controller of Stores. Two months later, during a session on an Appropriation Bill, Lo expressed his strong opposition towards the monopoly: "despite all official explanations, I cannot escape the feeling that there is something radically wrong in the operation of the Sand monopoly." 37 The Colonial Secretary replied that "queues and delays" would not recur. ${ }^{38}$ In 1956, another lawmaker questioned the government, complaining about the soaring cost of government sand prices, as well as the poor quality of its sand, and suggested the establishment of a Sand Board represented by building specialists. ${ }^{39}$ The government's reply was positive, ${ }^{40}$ but a follow-up was never made.

When the exposed sources of sand were near exhaustion, marine sand found on the seabed in sheltered coves was tapped. Although "a fleet of 12 dredges" existed as early as 1950/1951; the first obvious use of dredgers to collect sand deposited on seabed was reported in the year 1958/1959 in connection with exploitation in Chek Keng Hoi (Long Harbour) where sand lied below "eight feet of silt". In March 1956, Legislator Man Wai Lo told the government that "I have information from a reliable source that the supply of sand within our territories will be exhausted within two years."41 The Financial Secretary replied that:

I may say that when this matter was brought to my attention over twelve months ago, the forecast was not two years; it was six months. But since then, intensive searches all over the Colony for suitable building sand have been carried out, and the particular deposit to which I referred four weeks ago looks as if it will keep us going for some time yet. I am all in favour of his [i.e., Lo's] suggestion that sand should be imported, and if he knows of good sand outside the Colony's borders.. thope hill let it be known that

\footnotetext{
${ }^{36}$ Hong Kong Hansard (1949a: p.3).

${ }^{37}$ Hong Kong Hansard (1949b: p.100).

${ }^{38}$ Hong Kong Hansard (1949c: pp.127-128).

${ }^{39}$ Hong Kong Hansard (1956b: pp.116-117).

${ }^{40}$ Hong Kong Hansard (1956c: p.168).

${ }^{41}$ Hong Kong Hansard (1956b: pp.116-117).
} 
we shall be very pleased indeed if somebody can go and get it. As I said before, no difficulties will be placed in the ${ }^{42}$ (Squared brackets authors').

Someone who knew and could obtain good sand outside Hong Kong did appear. In 1957, Hong Kong saw a new player with technology superior to the SJA enter the sand-seeking industry. This was Yau Wing Company, which "on its own initiative, purchased a complete range of barges, dredgers, and towing crafts, and delivery on modern up-to-date basis" (Enclosure 4 to Memorandum to Executive Council dated 19 July 1960 for discussion on 27 July 1960). In 1960, it offered to carry out a free sand survey for the government in return for a contract renewal for three years without the need to submit a tender.

The SJA had apparently lost a contract awarded for the year $1957 / 1958$ and wrote on Christmas Eve 1956, a day not very socially amicable at the time, that a complaint letter accusing a certain "ambitious party" of monopolizing the trade and the adverse social effects of its members becoming unemployed. That party was certainly Yau Wing. Obviously, the government that did not favour the SJA and accepted Yau Wing's proposal and sought the endorsement of the Executive Council, arguing that "the supply of sand for use in the Colony is beginning to give rise to grave concern".

Yau Wing's emergence was not unchallenged but the government was firm. Questioned in 1965 by Lawmaker Yuet Keung Kan about Yau Wing's position in relation to the sand monopoly, the government explained its current sand supply policy and justified its past contracts with Yau Wing as the sole de facto supplier due to its superior and expensive modern equipment and explained why the contract with this company had to continue to 1969. It denied that Yau Wing had any status as a "contractual monopoly".

The Monopoly's purposes have remained unchanged, with the added aim of ensuring an adequate supply at all times for the construction industry, in the face of its extremely

\footnotetext{
${ }^{42}$ Hong Kong Hansard (1956b: p.167).
} 
rapid growth of recent years. It has achieved its purposes. As I have said, the contractor (Yau Wing) does not have a contractual monopoly, no "exclusive right" to use Mr KAN'S phrase. Under the contract Government undertakes to take a minimum quantity and the contract to supply a maximum quantity. There is no contractual reason why Government should not make purchases from other suppliers as well. Offers have been received from time to time, although none for over two years, but they have not been competitive.

Equally the Government Monopoly itself does not exercise a complete monopoly of the market and imports may be licensed subject to certain conditions; although they will not normally be permitted in circumstances where they might prejudice the disposal of the sand Government is committed by contract to purchase.

To return to the Monopoly's contracts... He was awarded his first contract by tender in 1954, his second in 1955, also by tender, at a slightly higher rate. During the course of this latter contract it became clear that we could no longer rely on taking sand from the Colony's beaches in the traditional junk. Annual sales had risen from 116,000 cubic yards in 1948 to 500,000 cubic yards in 1955 . It had become necessary to win sand from the sea-bed by the use of dredgers and pumps and transport it in larger, stronger, lighters. The contractor offered to acquire the necessary additional equipment at once and to open up new areas at his own expense, in return for a year's extension at existing rates. This was agreed.

It had also become clear that annual contracts were inadequate for the capital investment now involved. A two-year contract for 1957-58 was awarded to Yau Wing, again by tender, at rates which were again higher. Next a three-year contract covering 1959 to 1961 was awarded to Yau Wing, once again by tender. Both tenders were awarded on the advice of Executive Council. 
During 1960, with the continued increase in the consumption of sand, now nearing a million cubic yards a year, it became clear that a survey of the Colony's sand reserves was a matter of urgency. Government did not have the necessary equipment. The contractor offered to carry out the survey with his own equipment free of charge, under the direction of the Director of Public Works, in return for a three year extension of his contract at the same rates. This offer was accepted on the advice of Executive Council and the contract renewed for the three years 1962 to 1964 at the same rates.

Although the survey revealed substantial new deposits, which were tappable by the use of additional modern equipment, it became clear that if demand remained at its current high level and, even more so, if it continued to grow as it showed signs of doing, it would be necessary to import large quantities of sand if the Colony's own reserves were not to be run down rapidly.

At this time the contractor was approached by the Kwangtung Metals and Minerals Export Company with a suggestion that the Colony should make a bulk purchase of sand from China. Agreement was reached on the purchase of 2.2 million cubic yards from Sha Yu Chung off the shores of Mirs Bay, the total cost being $\$ 8.50$ a cubic yard...This contract received the approval of the Finance Committee of this Council. It was fortunate that we were able to make arrangements for these additional bulk supplies for demand.

When considering this contract, [the] [sic] Finance Committee expressed some concern at the fact that the contract had been so long in the hands of one firm and suggested that consideration should be given to some arrangement that would bring it to an end or put the award once again on a competitive tender rather than a negotiated basis. The most serious consideration was given during 1963 to this problem, but in the event 
at the beginning of 1964, Government came to the conclusion that in the circumstances it must recommend the award of a negotiated contract. This course was finally adopted on the advice of Executive Council and with the approval of the Finance Committee of this Council. The contract is for five years to 1969.

The circumstances leading to this decision are already fully known to those honourable Members of this Council who were members of the Finance Committee in March last year, but I shall repeat them today [sic]. First, the contractor must have at his disposal modern equipment of a capital value estimated, when new, at between $\$ 24$ million and $\$ 30$ million. Secondly, it is clear that we should in present circumstances take at least 90\% of our requirements from China, if China will supply. Thirdly, demand remains at a very high level and it is more important than ever that there should be no interruption in supplies to the construction industry. ${ }^{43}$

Innovation of a monopsony via purchase of new equipment thus officially embraced by the government to support it as part of the operation of the Sand Monopoly. One might surmise that by this time the new sources would remove some of the original reasons for the monopoly, i.e. beach and cultivation protection plus the need for building a strategic reserve. Yet, the China factor was considered critical, and the government ruled out the feasibility of finding another good supplier that could obtain sand from China.

It is possible that, given adequate time for preparation (and we examined the problem and reached the point of decision in plenty of time) another firm could acquire, and would be capable of operating efficiently, adequate dredging equipment and lighterage in spite of its high capital cost. There is some room for doubt, however. Then, we are not the only parties to the present arrangement. Yau Wing are known to be acceptable to the Chinese authorities for the conduct of operations in Chinese territory and the

\footnotetext{
${ }^{43}$ Hong Kong Hansard (1965: pp.224-226).
} 
present arrangements have been working well and, I believe, to the satisfaction of both parties. There would seem therefore to be potential dangers in changing them. We could not expect the Chinese authorities to accept automatically just any firm we might choose to select by tender to operate in China.

The focus of this paper is however not on the exogenous conditions affecting Hong Kong sand supply but whether the establishment of a monopoly as a state trading firm could solve an earlier ecological problem. Indeed, as the supply condition change drastically due to the abundant supply of sand from China and the new technology that anyone (including the government) could use to expand the supply of sand, the issue of the ecological implication of over-exploitation of a common resource became moot.

The government also ruled out the possibility of it collecting sand on its own or abandoning its sand monopoly and letting the free market supply the sand. There could not be any free market given that China would only supply sand to Yau Wing. ${ }^{44}$

Four years later, when the 1969 contract was due to expire, Kan again questioned the government's policy on sand supply and asked what further study it had promised in 1965 had been carried out. The then-Acting Financial Secretary, Mr. C.P. Haddon-Cave, famous for his "positive non-interventionism" praised by Milton Friedman, replied that while the government would keep on reviewing the matter, there were difficulties in departing from the status quo. However, the demand for sand and, hence, reliance on China was not as high as expected. ${ }^{45}$

The key issue of the political debates over the sand monopoly was predicated on the belief that had the supply from China been cut, Hong Kong would have had to stop building its reinforced concrete high-rise buildings. The reality was that while China supplemented the local sand supply, the deposits of sand in Hong Kong were rather plentiful. The China factor,

\footnotetext{
${ }^{44}$ Hong Kong Hansard (1965: pp.224-226).

${ }^{45}$ Hong Kong Hansard (1969: pp.224-226).
} 
which favoured Yau Wing, must be seen in light of the official 1965 statements examined earlier: the real reason for relying on China was not due to a shortage in the local supply of sand, as new sources were "trappable by the use of additional modern equipment," but to the desire to stockpile sand in its natural state. To what extent this was a strategic political consideration is something for historians to ponder. In fact, Yiu Wing's study discovered a lot of new local sources of sand. Although it was a known fact that only Yiu Wing might have obtained its sand from China, the argument that only it had access to modern capital was hard to believe.

\section{Facts against the Sand Monopoly}

The pre-war concept of the monopoly was based on the idea that it could regulate sand mining and, thereby, minimise conflicts between sandmen and villagers was essential because local sand supplies were limited. Our study, based on published official reports not adduced by the official statements in favour of the monopoly in the Legislative Council, found that post-war enforcement by the sand monopoly was ineffective and that local sand supplies were huge. Pre-war lawmakers assumed that sand could only be obtained by manually removing sand from sand bars and had no idea of how much marine sand was deposited on the seabed.

\section{Enforcement Ineffective}

The Sand Monopoly did not effectively control sand mining. From both private writings and official reports, we can see that the main local source of sand was initially sandy beaches in the New Territories. This was natural as the removal of exposed sand from beaches is a direct method. It is highly likely that the method of removal onto barges as transport tools was simply manual with little help of machinery. However, while this method entailed low private cost of exploitation, it incurred high public cost of enforcement. As no machinery was needed, this had to be the quickest and most profitable method of exploitation for both licensed and illegal sand excavators. Entry to the sand removal industry had to be easy. As tedious concurrent permission of the District Lands Office and local village representatives had also to be sought, enforcement of the sand law by the sand monopoly was costly. 
In the Financial Report of 1939, it was stated that the 25 beaches "were rested until sufficient fresh deposits of sand had accumulated." This was surely an indication of a good resource management intention but the sand law was not always observed. In 1939, there were 13 prosecution cases. A total of 19 persons appeared in magistracy courts; 12 were convicted, 2 bound over and 5 discharged. (Section VI, Financial Report for the Year 1939 dated 25 April 1940) They showed that the government sand monopoly face competition from poachers. We had no record of these cases but it is likely that they all involved illegal mining of sand from beaches. Besides, sand removers also ran easily into conflict with local farmers and landlords.

Well after the return of the British administration, there were signs that the lowest cost method of simply removing sand from beaches was also the most socially problematic. Good evidence of this state of affairs can be found in the following extracts from the memoir of James Hayes (1980), a District Officer:

Again in retrospect, it was of interest that, on my brief attachment to the District Office South when I first arrived in Hong Kong in 1956, I went with the District Officer to Tung Chung and Sha Lo Wan, on North Lantau, in connection with sand-taking by government contractors from the Sand Monopoly. This undertaking, regulated by permit, was usually cleared in advance with the District Officer and the elders, to try to save trouble later, but it often gave rise to a crop of difficulties. Villagers feared that the cultivated land behind the beaches would be damaged by the sea if protective sand bars were removed. This was a long-standing problem. One of my predecessors as District Officer South, Mr. Walter Schofield, mentions it in his reminiscences of the 1920s, and things had changed very little in this respect in my time. Sand-taking from remote beaches continued through my service as District Officer, and when the time came to get sand from local beaches for construction work on the Shek Pik Reservoir in 1960, I recall difficulties with villagers on South Lantau for the same reasons (Hayes 1980: p.63). 
In any case, all departmental reports after 1960 mentioned dredging as the means of exploitation till the relocation of the Sand Monopoly to PWD. The key sites in this era of marine dredging were in Tide Cove, Tolo Harbour. This source called for more sophisticated mechanical tools and vessels then simply removing sand from beaches or sand banks along stream courses. The techniques were much more capital intensive but it was much easier for the sand monopoly to enforce against illegal exploitation as the marine police, which expanded fast after the war, could easily monitor dredging and shipping of sand. This method thus in short involved higher private costs of exploitation, compensated by rising property prices, and lower public enforcement costs due to fewer possible entrants.

\section{New Sources of Sand up to 1997 Found}

New sources of marine sand were found from time to time and could be exploited through dredging.

Before September 1939, sand was only allowed to be removed from 25 beaches on Lantau and Lamma Islands. From September 1939, sand could only be collected from the seabed at Gin Drinker's Bay, Tai Lam Chung, nullahs and stream courses (Section VI, Financial Report for the Year 1939, dated 25 April 1940).

Table 1 shows the sources of sand, amount of sand collected and number of prosecutions under the Sand Ordinance year by year from 1946. As shown in this table, postwar exploitation first began at the beaches and streams of Tai Lam Chung. The new supply area So Kwun Wat, Castle Peak Bay, emerged. It lasted for about six years from 1948. Probably, by this time, the sources on Lantau Island and in Gin Drinker's Bay were almost exhausted. The latter, soon subject to rapid urbanization of rural Tsuen Wan, was mentioned for the last time in the 1948/1949 Store's Department Report.

Yet, new sources further and further away from the coast, and thus no conflict with coastal users, were discovered. The next major sources of beach sand for the following four years came from Soko Islands near the southwestern end of Lantau the (two years from 1954); 


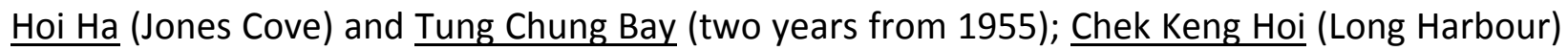
(two years from 1957); and Pak Sha Wan Hoi (Hebe Haven) (two years from 1958). For ten years from 1959, Tide Cove became the dominant source of sand, though supplementary supply came from reworking the retired Castle Peak Bay (Tai Lam Chung), using "modern equipment" (Para 76, p.15 Report 1960/1961).

Table 1: Sources of marine sand 1939 to 1979

\begin{tabular}{|c|c|c|c|}
\hline Fiscal Year & Sources of Sand & $\begin{array}{l}\text { Remarks } \\
\text { (Number of persons } \\
\text { prosecuted[convicted] } \\
\text { under the Sand } \\
\text { Ordinance) } \\
\end{array}$ & References \\
\hline Before 1939 & $\begin{array}{l}25 \text { beaches, the majority of } \\
\text { which on Lantau and Lamma } \\
\text { Islands }\end{array}$ & & $\begin{array}{l}\text { Para. } 48, \text { Report } \\
\text { of the Controller } \\
\text { of Stores for the } \\
\text { Year } 1939, \mathrm{p} \text {. } \\
\text { Financial Report } \\
\text { for the Year } 1939\end{array}$ \\
\hline $1946 / 1947$ & $\begin{array}{l}\text { Bathing beaches; } \\
\text { beaches adjacent to roads }\end{array}$ & Illegal & $\begin{array}{l}\text { Para. 30, } \\
\text { Departmental } \\
\text { Report by } \\
\text { Government } \\
\text { Store and Sand } \\
\text { Monopoly (p.5) }\end{array}$ \\
\hline $1948 / 1949$ & $\begin{array}{l}\text { Stream course and beach at Tai } \\
\text { Lam Chung; } \\
\text { beaches at Gin Drinker's Bay; } \\
\text { beaches at So Kun Wat }\end{array}$ & & $\begin{array}{l}\text { Para. 5, } \\
\text { Departmental } \\
\text { Report by } \\
\text { Government } \\
\text { Store and Sand } \\
\text { Monopoly }\end{array}$ \\
\hline $1950 / 1951$ & $\begin{array}{l}\text { Stream course and beach at Tai } \\
\text { Lam Chung; } \\
\text { outlying beaches; } \\
\text { Shatin area; } \\
\text { Hoot La Wan; } \\
\text { Tong Ku; } \\
\text { Soko Islands }\end{array}$ & $\begin{array}{l}34 \text { contractors } \\
\text { persecuted for } \\
\text { contravention of the } \\
\text { Sand Ordinance } 1935\end{array}$ & $\begin{array}{l}\text { Para. 5, } \\
\text { Departmental } \\
\text { Report by } \\
\text { Government } \\
\text { Store and Sand } \\
\text { Monopoly (p.9) }\end{array}$ \\
\hline
\end{tabular}




\begin{tabular}{|c|c|c|c|}
\hline 1951/1952 & $\begin{array}{l}\text { Bay at So Kam Wat, Tap So Kok } \\
\text { and Sha Chau; } \\
\text { Tong Kui Islands }\end{array}$ & & $\begin{array}{l}\text { Para. 42, } \\
\text { Departmental } \\
\text { Report by } \\
\text { Government } \\
\text { Store and Sand } \\
\text { Monopoly (p.9) }\end{array}$ \\
\hline 1952/1953 & $\begin{array}{l}\text { Tai Lam Chung; } \\
\text { So Kun Wat; } \\
\text { Bay of Chuk Kui Wan; } \\
\text { Trio Islands; } \\
\text { Cheung Sa Wan; } \\
\text { Kee Lung Wai }\end{array}$ & & $\begin{array}{l}\text { Para. 65, } \\
\text { Departmental } \\
\text { Report by } \\
\text { Government } \\
\text { Store and Sand } \\
\text { Monopoly (p.14) }\end{array}$ \\
\hline 1953/1954 & $\begin{array}{l}\text { Tai Lam Chung; } \\
\text { So Kun Wat; } \\
\\
\text { Pak Kok Tsui; } \\
\text { Lau Foo Sau; } \\
\text { Mui Wo; } \\
\text { Ma Chi Lung }\end{array}$ & & $\begin{array}{l}\text { Paras. } 56 \text { and } 58 \\
\text { Departmental } \\
\text { Report by } \\
\text { Government } \\
\text { Store and Sand } \\
\text { Monopoly (p.14) }\end{array}$ \\
\hline \begin{tabular}{|l|l}
$1954 / 1955$ \\
\end{tabular} & $\begin{array}{l}\text { New sites: } \\
\text { Pak Mun; } \\
\text { Tung Chung; } \\
\text { Soko Islands; } \\
\text { South Lantao }\end{array}$ & & $\begin{array}{l}\text { Para. } 48 \\
\text { Departmental } \\
\text { Report by } \\
\text { Government } \\
\text { Store and Sand } \\
\text { Monopoly (p.13) }\end{array}$ \\
\hline \begin{tabular}{|l|l}
$1955 / 1956$ \\
\end{tabular} & $\begin{array}{l}\text { Pak Mun; } \\
\text { Tung Chung; } \\
\text { Soko Islands; } \\
\text { Sha Lo Wan }\end{array}$ & & $\begin{array}{l}\text { Para. } 94 \\
\text { Departmental } \\
\text { Report by } \\
\text { Government } \\
\text { Store and Sand } \\
\text { Monopoly (p.22) }\end{array}$ \\
\hline 1956/1957 & $\begin{array}{l}\text { Bay of Tung Chung; } \\
\text { Hoi Ha }\end{array}$ & $\begin{array}{l}\text { "A survey of the } \\
\text { Colony's sand } \\
\text { resources.... } \\
\text { ascertained that } \\
\text { sufficient supplies } \\
\text { were available to meet } \\
\text { the needs of the } \\
\text { building industry for a } \\
\text { number of years to }\end{array}$ & $\begin{array}{l}\text { Para. } 68 \\
\text { Departmental } \\
\text { Report by } \\
\text { Government } \\
\text { Store and Sand } \\
\text { Monopoly (p.18) }\end{array}$ \\
\hline
\end{tabular}




\begin{tabular}{|c|c|c|c|}
\hline & & come." & \\
\hline $1957 / 1958$ & $\begin{array}{l}\text { Hoi Ha (Jones Cove); } \\
\text { Chek Keng Hoi (Long } \\
\text { Harbour) } \\
\text { Tung Chung Bay (winter) }\end{array}$ & & $\begin{array}{l}\text { Para. } 68 \\
\text { Departmental } \\
\text { Report by } \\
\text { Government } \\
\text { Store and Sand } \\
\text { Monopoly } \\
\text { (pp.12-13) }\end{array}$ \\
\hline $1958 / 1959$ & $\begin{array}{l}\text { Chik King Hoi (Long Harbour) } \\
\text { Pak Sha Wan Hoi (Hebe Haven) }\end{array}$ & & $\begin{array}{l}\text { Para. } 58 \\
\text { Departmental } \\
\text { Report by } \\
\text { Government } \\
\text { Store and Sand } \\
\text { Monopoly (p.11) }\end{array}$ \\
\hline $1959 / 1960$ & $\begin{array}{l}\text { Tide Cove; } \\
\text { Pak Sha Wan Hoi (Hebe Haven) }\end{array}$ & & $\begin{array}{l}\text { Para. } 59 \\
\text { Departmental } \\
\text { Report by } \\
\text { Government } \\
\text { Store and Sand } \\
\text { Monopoly (p.11) }\end{array}$ \\
\hline $1960 / 1961$ & $\begin{array}{l}\text { Tide Cove; } \\
\text { Castle Peak Bay (re-opened) }\end{array}$ & & $\begin{array}{l}\text { Para. } 76 \\
\text { Departmental } \\
\text { Report by } \\
\text { Government } \\
\text { Store and Sand } \\
\text { Monopoly (p.15) }\end{array}$ \\
\hline $1961 / 1962$ & $\begin{array}{l}\text { Tide Cove; } \\
\text { Castle Peak Bay (Tai Lam } \\
\text { Chung, So Kwun Wat) }\end{array}$ & & $\begin{array}{l}\text { Para. } 88 \\
\text { Departmental } \\
\text { Report by } \\
\text { Government } \\
\text { Store and Sand } \\
\text { Monopoly (p.15) }\end{array}$ \\
\hline $1962 / 1963$ & $\begin{array}{l}\text { Tide Cove; } \\
\text { Tai Lam Chung; } \\
\text { Tai Ho Bay, Lantau; } \\
\text { Tai Tam Bay }\end{array}$ & & $\begin{array}{l}\text { Paras. 111-114 } \\
\text { Departmental } \\
\text { Report by } \\
\text { Government } \\
\text { Store and Sand } \\
\text { Monopoly } \\
\text { (pp.17-18) }\end{array}$ \\
\hline \multicolumn{4}{|l|}{$1963 / 1964$} \\
\hline $1964 / 1965$ & $\begin{array}{l}\text { A new sand contract to obtain } \\
\text { sand from the Chinese Mainland }\end{array}$ & & $\begin{array}{l}\text { Para. } 71 \\
\text { Departmental }\end{array}$ \\
\hline
\end{tabular}




\begin{tabular}{|l|l|l|l|}
\hline & $\begin{array}{l}\text { for the next 5 years from 1 } \\
\text { January 1965. }\end{array}$ & & $\begin{array}{l}\text { Report by } \\
\text { Government } \\
\text { Store and Sand } \\
\text { Monopoly (p.12) }\end{array}$ \\
\hline $1965 / 1966$ & & & \\
\hline $1966 / 1967$ & & & \\
& $\begin{array}{l}\text { Tide Cove; } \\
\text { Sha Yu Chung (ceased 26 June } \\
1967)\end{array}$ & $\begin{array}{l}\text { Tung Chung site } \\
\text { worked out }\end{array}$ & $\begin{array}{l}\text { Para. 109 } \\
\text { Departmental } \\
\text { Report by } \\
\text { Government } \\
\text { Store and Sand } \\
\text { Monopoly (p.15) }\end{array}$ \\
\hline $1968 / 1969$ & $\begin{array}{l}\text { Tide Cove (exhausted November } \\
\text { 1968); } \\
\text { Sha Yu Chung (resumed 9 } \\
\text { November 1968) }\end{array}$ & $\begin{array}{l}\text { Para. 105 } \\
\text { Departmental } \\
\text { Report by } \\
\text { Government } \\
\text { Store and Sand } \\
\text { Monopoly (p.15) }\end{array}$ \\
& $\begin{array}{l}\text { Para. 100 } \\
\text { Departmental }\end{array}$ \\
& $\begin{array}{l}\text { Report by } \\
\text { Government } \\
\text { Store and Sand } \\
\text { Monopoly (p.15) }\end{array}$ \\
\hline
\end{tabular}

The most persuasive proof of an ample local sand supply was the source of filler for the Port and Airport Strategy (PADS), which commenced in 1989 and was completed in 1998. The filler came from marine sand deposits. During PADS, most of the world's sand dredgers were employed in Hong Kong to pump sand from its deep seas and used as landfill to build Chek Lap Kok International Airport and related projects.

Besides relying on dredging, sand could be produced by machine. The technology involved became so sophisticated from an engineering standpoint that it was beyond the competence of a department that specialized only in purchasing and controlling the inventory of purchased materials. There were many local granite quarries from which solid rocks mined could be crushed to produce sand. The well-known quarries worked from the 1960 s to the early 1990s were those at Tai Sheung Tok (Anderson Road Quarry), Shek O Road Picnic Bay (Sok Kwo Wan, Lamma Island) (Shui On); Tai Shek Kwu, Shatin; Shatin Wai, Shatin; and Mount Butler 
(government quarry). This was the most capital intensive and costly method of producing sand but justified by escalation in property values. Enforcement cost was low as huge fixed cost of entry limited the number of entrants and activities were carried out on plants on land. This method involved huge private cost of production but low public cost of enforcement.

The government entered into contracts with quarry operators for manufactured sand, but allowed them to also sell sand directly to builders. A contract for the supply of "manufactured sand" was signed between the colonial government and the Pioneer Concrete Group to operate from 1 October 1976. By this time, the recreational value of sandy beaches and the cost of sand dredging to marine fish culture and water quality had risen substantially, as evidenced by the creation of the Environment Branch in the Government Secretariat. During the 1970s, as for sand dredging, contracts were awarded to supply sand "to Government from waters not adjacent to the coastline of Hong Kong," which meant sources controlled by China. However, when PADS was implemented, the Colonial Government was quick to resort to sand deposited in the deep sea rather than relying on China alone.

\section{Wholesale Prices of Sand Fell after 1981}

The most striking fact is that after the dissolution of the sand monopoly in 1981, wholesale prices of sand actually fell. Figure 1, which traces such prices from 1947 to 2007, tells the story. When the Monopoly's sand sale pieces were net of an assumed profit margin of $15 \%$, they were still well above the post 1981 level in real terms.

\section{Figure 1}




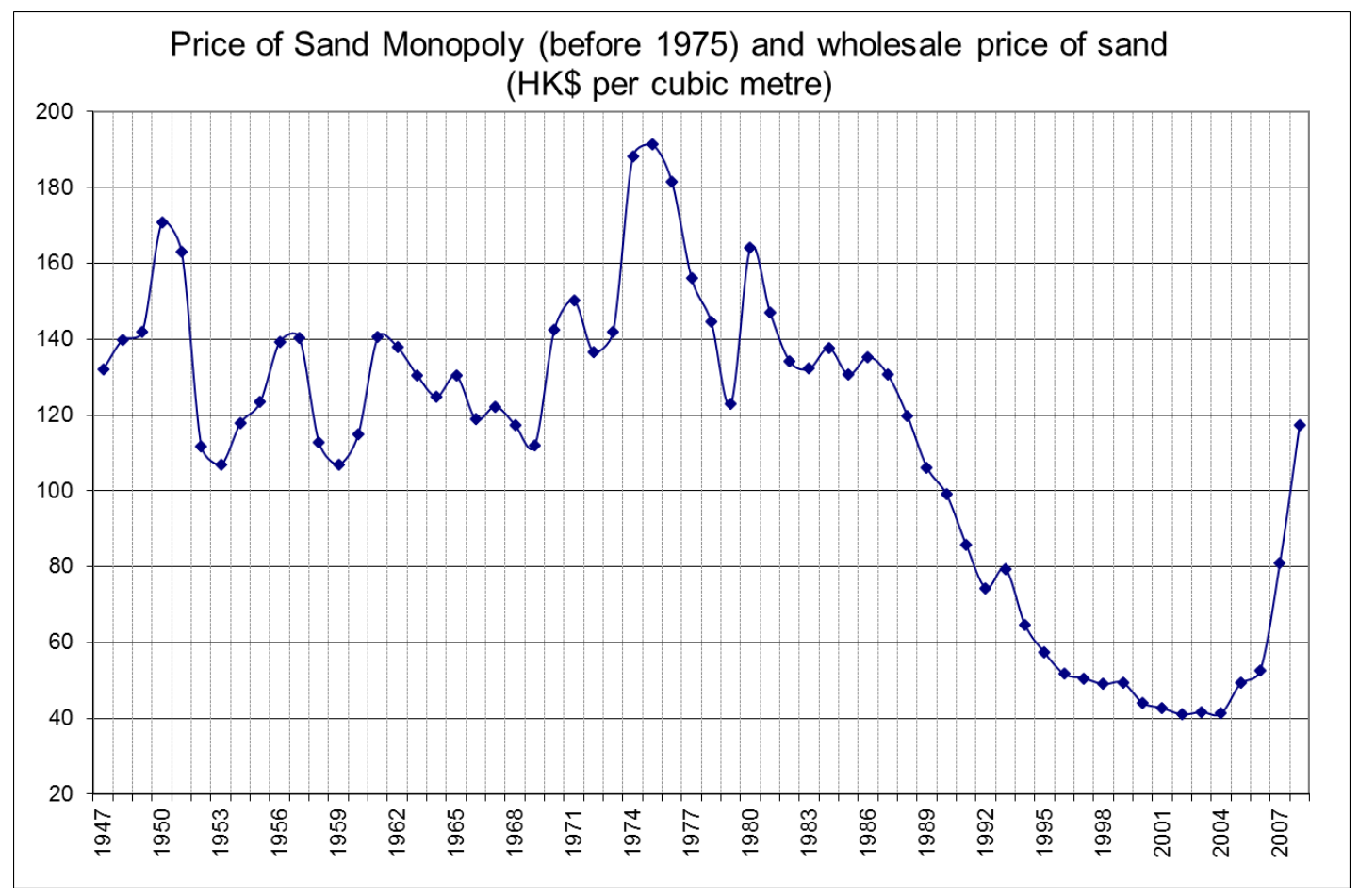

\section{Conclusion}

Triggered by the adoption of the use of concrete as building materials in the 1920, the mining of sand for building construction in Hong Kong commenced with manual collection on beaches as if it was common property, which was de jure Crown property but subject to open access. The ensuing disorderly situation prompted the colonial government to pass the Sand Ordinance of 1935 which established a sand monopoly, located inside the Stores Department, with vast and extensive legal authority in the licensing, stocking, and trading of sand. The monopoly was created as a solution to the problem of open access. The study showed that the creation of a state monopoly over sand before World War II was likely the best solution, and certainly better than the second best solution of simply defining the rights to sand extraction, as licensing could incur far more transaction costs to enforce. The role of transaction costs in economics is well explained by Coggan et al (2010). A monopoly is a more direct way to deal with the problem of over-utilizing a common access resource. However, a static monopoly comes with a high cost unless it innovates to lower the long run average cost of production. 
This study found that contrary to the monopoly's original intent, it could not effectively crack down on sand thieves and its reliance on Chinese sand supplies was not as great as imagined. One might argue, based on facts officially admitted to in 1965, that the Colonial Government deliberately stockpiled sand on the seabed to wait for something politically major such as PADS. In any event, this compelled the local construction industry to pay higher sand prices during the life of the monopoly.

Unlike that for water and electricity, sand production by the Sand Monopoly did not appear to exhibit the production features of a scale economy. No new technology was introduced after Yau Wing entered the scene. Thus, the natural monopoly story with a Schumpeterian innovation argument cannot stand up to criticism. Schumpeterian influence is in terms of the power force of creative destruction, which can come from within the system, as well as from outside the system. The point we want to stress is not the existence or absence of a monopoly, but the mode of monopoly. There is ample economic evidence to show that state trading monopolies do not work well in terms of efficiency or innovation. The history of Hong Kong's Sand Monopoly can, therefore, be regarded as another classic textbook example of the failure of a state trading monopoly after the Fish Marketing Organisation (Lai and Yu 2002a), which simply raised prices without innovation. Its demise makes economic sense.

Acknowledgements: we are grateful to the assistance of Mr. Dennis Cheung for his archival research and the useful comments by Prof. Stephen N.G. Davies on the revised manuscript. All faults are the authors.

\section{References}

1. Anderson, T.L. and Hill, P.J., (1981), "Establishing Property Rights in Energy: Efficient vs. Inefficient Processes," Cato Journal, No. 1, pp.87 -105.

2. Burnell, S.J. and Sheppard D.K. (1992), “Upgrading New Zealand's Competitive Advantage: a Critique and Some Proposals," New Zealand Economic Papers, Vol.26, No.1, pp.101-125. 
3. Chaudry, S.A. (2000), "Significance of the Small and Medium Enterprises (SMEs) Sector in Pakistan and Assessment of its Employment Potential," The Lahore Journal of Economics, Vol.5, No.1, pp.23-59.

4. Chau, K.W. and Ho, W.K.O. (2002), "A Time Series Analysis of the Price of Epinephelus," Aquaculture Economics and Management, Vol.6, Nos.3 \& 4, pp.215-230.

5. Cheung, Steven N.S. (1998), "The Transaction Costs Paradigm," Vol. 36, No.4, Economic Inquiry, pp.514-421.

6. Cheung, S.N.S. (1970), "The Structure of a Contract and the Theory of a Non-exclusive Resource." Journal of Law and Economics. 13, No.1, pp.49-70.

7. Clarke, G.R.G. and Wallsten, S.J. (2002), “Universal(ly Bad) Service: Providing Infrastructure Services to Rural and Poor Urban Consumers," World Bank Policy Research Working Paper 2868.

8. Coase, R.H. (1960),"The Problem of Social Cost," Journal of Law and Economics, Vol. 3, No.1, pp. 1-44.

9. Coggan, A., Whitten, S.M. and Bennett, J. (2010), "Influences of Transaction Costs in Environmental Policy," Ecological Economics, Vol. 69, No. 9, pp. 1777-1784.

10. Farrant, A. (2004), "Frank Knight, Worst-Case Theorizing, and Economic Planning: Socialism as Monopoly Politics," History of Political Economy, Vol. 36, No.3, pp. 497-504.

11. Fielding, G.J. and Klein, D.B. (1993), "How to Franchise Highways," Journal of Transport Economics and Policy, Vol.27, No.2, pp.113-130.

12. Gaudet, G. (1988), “On Comparing Monopoly and Competition in Exhaustible Resource Exploitation," Journal of Environmental Economics and Management, Vol.15, No. 4, pp. 412418. 
13. Gordon, H. (1954), "The Economic Theory of a Common-Property Resource: The Fishery." Journal of Political Economy, 62, No.2, pp.124-142.

14. Hayes, J. (1980), "The New Territories Twenty Years Ago: From the Notebooks of a District Officer," Journal of the Hong Kong Branch of the Royal Asiatic Society, Vol.2, No.1, pp.60-70.

15. Hong Kong Government (1982), Annual Report, Hong Kong: Government Printer.

16. Hooper, P., Hutcheson, S. and Nyathi, M. (1996), "The Challenge of Liberalising Domestic Airline Competition in a less Developed Country," Transportation, Vol.23, No.4, pp.395-408.

17. Howorka, V.M. (1981), "Econometric Estimates of Scale Economies in Electric Power Generation: the Role of Excess Capacity," University of Florida, Department of Economics, PURC Working Paper, No.81-09.

18. Hutchcroft, P.D., 1991, "Oligarchs and Cronies in the Philippine State the Politics of Patrimonial Plunder," World Politics, Vol. 43, No.3, pp.414-450.

19. Kim, T.G, Grigalunas, T.A. and Han, K.N. (2008), "The Economic Costs to Fisheries because of Marine Sand Mining in Ongjin Korea: Concepts, Methods, and Illustrative Results," Ecological Economics Vol. 65, No. 3, pp. 498-507.

20. Lai, L.W.C. (1993), "Marine Fish Culture and Pollution - An Initial Hong Kong Empirical Study," Asian Economic Journal, Vol.VII, No.3, pp.333-351.

21. Lai, L.W.C. and Lorne, F.T. (2014), "Transaction Cost Reduction and Innovations for Spontaneous Cities: Promoting a "Meeting" between Coase and Schumpeter," Planning Theory, Vol. 13, No.2, pp. 170-188. 
22. Lai, L.W.C. and Yu, B.T. (1995), "The 'Hong Kong' Solution to the Overfishing Problem: A Study of the Cultured Fish Industry in Hong Kong," Managerial and Decision Economics, Vol.16, No.5 (September-October), pp.525-535.

23. Lai, L.W.C. and Yu, B.T. (2002a), "The Hong Kong Fish Marketing Organisation: a Case Study of the Financial Problem of a Legal Monopoly," Pacific Economic Review, Vol.7, No.1 (February), pp.85-96.

24. Lai, L.W.C. and Yu, B.T. (2002b), "The Evolution of the Fry Market in the Marine Fish Culture Industry of Hong Kong: an Economic Perspective," Aquaculture Economics and Management, Vol.6, Nos.3 \& 4, pp.191-214.

25. Lai, L.W.C., Davies, S.N.G. and Lorne, F.T. (2008), "The Political Economy of Coase's Lighthouse in History (Part I): a Review on the Theories and Models of the Provision of a Public Good," Town Planning Review, Vol. 79, No. 4, pp. 395-425.

26. Lai, L.W.C., Chau, K.W. and Cheung, P.C.W. (2012), "Scale Economies of the Franchised Buses and Ferries of Hong Kong, 1948 to 1998," Review of Urban and Regional Development Studies, Vol.24, No.3, pp.121-140.

27. Libecap, G.D. and Wiggins, S.N., (1984), "Contractual Responses to the Common Pool: Prorationing of Crude Oil Production," The American Economic Review, Vol. 74, No. 1, pp.87-98.

28. Lu, X., 1999. "From Rank-seeking to Rent-seeking: Changing Administrative Ethos and Corruption in Reform China," Crime, Law and Social Change, Vol. 32, No. 4, pp.347-370.

29. Mahoney, P. G. (2001), "The Common Law and Economic Growth: Hayek Might be Right," Journal of Legal Studies, Vol. 30, No.2, pp 503-525.

30. Morgan, D.R. (1992), "The Pitfalls of Privatization: Contracting without Competition," The American Review of Public Administration, Vol.22, No.4, pp.251-269. 
31. Olukoju, A. (2004), “'Never Expect Power Always': Electricity Consumers' Response to Monopoly, Corruption and Inefficient Services in Nigeria," African Affairs, Vol.103, No.410, pp.51-71.

32. Papathanassopoulos, S. (2005), “Europe: an Exemplary Landscape or Comprehending Globalization," Global Media and Communication, Vol.1, No.1, pp.46-50.

33. Paul, E. F. (2005), "Hayek on Monopoly and Antitrust in the Crucible of United States v. Microsoft; Paul, Ellen Frankel," New York University Journal of Law and Liberty, Vol. 1, pp. 167204.

34. Prager, J. (1994), "Contracting out Government Services: Lessons from the Private Sector," Public Administration Review, Vol.54, No.2, pp.176-184

35. Roberts, M.T. (2001), "The Unique Role of State Trading Enterprises in World Agricultural Trade: Sifting through the Rhetoric," Drake Journal of Agricultural Law, Vol.6, No.2, pp.287-315.

36. Schofield, W. (1977), "Memories of the District Office South, New Territories of Hong Kong," Journal of the Royal Asiatic Society, Hong Kong Branch, Vol.17, pp.144-156.

37. Slater, R. (2006), "The Case for Monopoly: Responses of the Major U.S. Airlines to DOT's Anti-predation Proposal," Antitrust Law \& Economics Review, Vol.33, No.1, pp.31-52.

38. Stiglitz, J.E. (1976), "Monopoly and the Rate of Extraction of Exhaustible Resources," American Economic Review,

39. Umbeck, J. (1981), "Might Make Rights: a Theory of the Formation and Distribution of Property Rights," Economic Inquiry, Vol.19, No.1, pp.38-59.

40. Waller, S.P. (1981), "Article 37 of EEC Treaty: State Trading under Scrutiny," Northwestern Journal of International Law \& Business, Vol.3, No.2, pp.662-683. 
41. Watts, M. (1984), "State, Oil, and Accumulation; from Boom to Crisis," Environment and Planning D: Society and Space, No. 4, pp. 403-428.

\section{Archival Materials}

Hong Kong Government Gazette:

30. Hong Kong Government (1903, February 27) "Government Notification No.94," The Hong Kong Government Gazette, pp.162-253.

31. Hong Kong Government (1905, May 26) “Government Notification No.328," The Hong Kong Government Gazette, pp.727-728.

32. Hong Kong Government (1907, April 5) "Government Notification No.218," The Hong Kong Government Gazette, p.389.

33. Hong Kong Government (1931, March 27) "Government Notification No.193," Hong Kong Government Gazette, p.184.

Hong Kong Hansard:

34. Hong Kong Hansard, (1934a, September 13), Reports of the sittings of the Legislative Council of Hong Kong. Hong Kong: Government Printer.

35. Hong Kong Hansard, (1934b, November 8), Reports of the sittings of the Legislative Council of Hong Kong. Hong Kong: Government Printer.

36. Hong Kong Hansard, (1935, November 28), Reports of the sittings of the Legislative Council of Hong Kong. Hong Kong: Government Printer.

37. Hong Kong Hansard, (1949a, January 12), Reports of the sittings of the Legislative Council of Hong Kong. Hong Kong: Government Printer. 
38. Hong Kong Hansard (1949b, March 30), Reports of the sittings of the Legislative Council of Hong Kong. Hong Kong: Government Printer.

39. Hong Kong Hansard (1949c, March 31), Reports of the sittings of the Legislative Council of Hong Kong. Hong Kong: Government Printer.

40. Hong Kong Hansard (1950, November 1), Reports of the sittings of the Legislative Council of Hong Kong. Hong Kong: Government Printer.

41. Hong Kong Hansard (1956a, March 11), Reports of the sittings of the Legislative Council of Hong Kong. Hong Kong: Government Printer.

42. Hong Kong Hansard (1956b, March 21), Reports of the sittings of the Legislative Council of Hong Kong. Hong Kong: Government Printer.

43. Hong Kong Hansard (1956c, March 28), Reports of the sittings of the Legislative Council of Hong Kong. Hong Kong: Government Printer.

44. Hong Kong Hansard (1965, March 11), Reports of the sittings of the Legislative Council of Hong Kong. Hong Kong: Government Printer.

45. Hong Kong Hansard (1969, July 2), Reports of the sittings of the Legislative Council of Hong Kong. Hong Kong: Government Printer.

Colonial Papers, British Government

46. "Government Stores," Colonial Office File No.53896/38. Hong Kong (British National Archive Reference: CO 129/572/13).

47. "Ordinance No.41 of 1934 - Sand," Colonial Office File No.33800/27/1934 Hong Kong (British National Archive Reference: CO 129/548/15). 
48. "Sand (Amendment) Ordinance - No.12 of 1938," Colonial Office File No.53719/38 Hong Kong (British National Archive Reference: CO 129/569/6).

Hong Kong Public Records

49. "Building: Question of Sand Supply for Building Purposes," General Correspondence Files, Building and Lands No.7/736/1946 (PRO Reference: HKRS156-1-138).

50. "Building Costs in the Colony: Short term Recommendation which can give immediate beneficial results to reduce costs by allowing Sand to be dug or dredged and graded by Private Enterprises," Correspondence Files, Building and Lands No.2/736/1949 (PRO Reference: HKRS156-1-1883).

51. "Removal of Sand from Foreshore at Kau Wa Keng Village," C.S.O. File No.4402/1906 (PRO Reference: HKRS58-1-36-13).

52. "Stone and Rubble on Foreshores," C.S.O. File No.1342/1925 (PRO Reference: HKRS58-1135-75).

53. "Unauthorised Removal of Sand from Foreshore near Mui Wo, Lan Tao Island," C.S.O. File No.1299/1920 (PRO Reference: HKRS58-1-95-10). 